\title{
Marine microalgae attack and feed on metazoans
}

\author{
Terje Berge ${ }^{1,2,4}$, Louise K Poulsen ${ }^{3}$, Morten Moldrup ${ }^{2}$, Niels Daugbjerg ${ }^{1}$ and Per Juel Hansen ${ }^{2}$ \\ ${ }^{1}$ Marine Biological Section, Department of Biology, University of Copenhagen, Copenhagen K, Denmark; \\ ${ }^{2}$ Marine Biological Section, Department of Biology, University of Copenhagen, Helsingør, Denmark and \\ ${ }^{3}$ DTU Aqua, Technical University of Denmark, Charlottenlund Castle, Charlottenlund, Denmark
}

\begin{abstract}
Free-living microalgae from the dinoflagellate genus Karlodinium are known to form massive blooms in eutrophic coastal waters worldwide and are often associated with fish kills. Natural bloom populations, recently shown to consist of the two mixotrophic and toxic species Karlodinium armiger and Karlodinium veneficum have caused fast paralysis and mortality of finfish and copepods in the laboratory, and have been associated with reduced metazooplankton biomass in-situ. Here we show that a strain of $K$. armiger (K-0688) immobilises the common marine copepod Acartia tonsa in a densitydependent manner and collectively ingests the grazer to promote its own growth rate. In contrast, four strains of $K$. veneficum did not attack or affect the motility and survival of the copepods. Copepod immobilisation by the $K$. armiger strain was fast (within $15 \mathrm{~min}$ ) and caused by attacks of swarming cells, likely through the transfer and action of a highly potent but uncharacterised neurotoxin. The copepods grazed and reproduced on a diet of $K$. armiger at densities below 1000 cells $\mathrm{ml}^{-1}$, but above 3500 cells $\mathrm{ml}^{-1}$ the mixotrophic dinoflagellates immobilised, fed on and killed the copepods. Switching the trophic role of the microalgae from prey to predator of copepods couples population growth to reduced grazing pressure, promoting the persistence of blooms at high densities. $K$. armiger also fed on three other metazoan organisms offered, suggesting that active predation by mixotrophic dinoflagellates may be directly involved in causing mortalities at several trophic levels in the marine food web.
\end{abstract}

The ISME Journal (2012) 6, 1926-1936; doi:10.1038/ismej.2012.29; published online 19 April 2012

Subject Category: microbial ecosystem impacts

Keywords: algal blooms; copepods; marine food web; mixotrophy; phytoplankton; prey size

\section{Introduction}

In terms of nutritional modes the free-living dinoflagellates represent one of the most diverse groups of unicellular eukaryotes in the marine food web. Half of the species are primarily phototrophic and possess permanent chloroplasts (that is, they are microalgae), while the other half lacks pigments and are primarily heterotrophic grazers and predators. Many species of both types have mixotrophic tendencies and can combine both phototrophy and heterotrophy in different ways (Stoecker et al., 2009; Hansen, 2011). The degree of mixotrophy varies along a spectrum from purely phototrophic to purely heterotrophic species (Jones, 1994). While a few primarily heterotrophic species can acquire phototrophy through the retention of chloroplasts from ingested prey for short periods of time (days) (Burkholder and Glasgow, 1997; Skovgaard, 1998; Lewitus et al., 1999; Jakobsen et al., 2000), several

Correspondence: T Berge, Marine Biological Section, Department of Biology, University of Copenhagen, Østre Farimagsgade 2D, Copenhagen 1353, Denmark

E-mail: tberge@bio.ku.dk

${ }^{4}$ Current address: Marine Biological Section, Department of Biology, University of Copenhagen, Strandpromenaden 5, 3000 Helsingør, Denmark

Received 21 November 2011; revised 23 February 2012; accepted 23 February 2012; published online 19 April 2012 primarily phototrophic species with permanent chloroplasts can supplement growth with heterotrophy by feeding on unicellular prey (Hansen, 2011). Mixotrophy in primarily phototrophic microalgae is especially common in harmful and toxic bloom species from coastal eutrophic waters (Burkholder et al., 2008; Place et al., 2012).

Typically, mixotrophic dinoflagellates catch motile prey using a so-called capture filament that functions similarly to a harpoon. Depending on the feeding mechanisms, the prey is either engulfed directly by membrane engulfment, or parts are sucked out by a microtubule supported feeding tube or peduncle (myzocytosis) (Hansen and Calado, 1999). In general, mixotrophic dinoflagellates differ from most grazers in the marine food web by having a large optimal prey size, often corresponding to their own size (Hansen and Calado, 1999). Tube feeding enables dinoflagellates to feed on very large prey (Berge et al., 2008a) and a few primarily heterotrophic dinoflagellates, generally not forming mono-specific high-density blooms, have been reported to ingest rotifers, nauplius and bivalve larvae, nematodes and even finfish by the use of a feeding tube (Calado and Moestrup, 1997; Vogelbein et al., 2002; Shumway et al., 2006; Jeong et al., 2010). This includes ingestion of fish in the primarily heterotrophic Pfiesteria piscicida, which can retain functional plastids from cryptophyte prey 
and thereby become mixotrophic (Burkholder and Glasgow 1997; Lewitus et al., 1999). In contrast, primarily phototrophic and potentially bloom forming dinoflagellates with permanent chloroplasts have not been reported to ingest metazoans (Hansen and Calado, 1999; Jeong et al., 2010). However, we observed this in a field sample from The Sound (Denmark). Unidentified dinoflagellates possessing chloroplasts were tube feeding on a copepod nauplius larva (Supplementary Video S1). Copepods are millimeter-sized abundant planktonic crustaceans and typically represent the most important metazoan grazers for the transfer of primary production to higher trophic levels in the sea (Ohman and Hirche, 2001). Generally in marine food webs, microalgae are prey and copepods grazers, and copepod grazing reduces microalgal biomass and controls the formation of blooms (Ohman and Hirche, 2001; Armbrust, 2009).

Based on inverted light microscopy (Supplementary Video S1) the microalgae feeding on the nauplius larva resembled members of the relatively recently described genus of bloom-forming and toxic microalgae Karlodinium (Daugbjerg et al., 2000). Species of Karlodinium are less than $20 \mu \mathrm{m}$ in length and $15 \mu \mathrm{m}$ in width and require electron microscopy and/or DNA sequence analyses for proper species identification (Bergholtz et al., 2005; de Salas et al., 2005), which was not available for this study. Species of Karlodinium possess permanent chloroplasts of haptophyte endosymbiotic origin (Bergholtz et al., 2005) and seem to be obligate phototrophs (that is, unable to survive without light). However, the two species investigated in this study Karlodinium armiger and Karlodinium veneficum are mixotrophic and use feeding tubes to phagocytise microalgal prey to obtain faster growth rates (Li et al., 1999; Berge et al., 2008a).

The widespread species $K$. veneficum represents one of the most problematic and well-studied toxic bloom-forming microalgae known (Garcés et al., 2006; Place et al., 2008; Mooney et al., 2009; Calbet et al., 2011) and has been recognised for its ichtyotoxicity (toxic to fish) since the 1950s (Braarud, 1957). Several aspects of its biology (Adolf et al., 2008), toxins (Deeds et al., 2002; Van Wagoner et al., 2010) and harmful effects on fish (Nielsen, 1993) have been described in detail and were recently reviewed (Place et al., 2011). The haemolytic and neurotoxic Karlotoxins (Deeds et al., 2002; Van Wagoner et al., 2010) produced by K. veneficum aid prey capture and are used directly to stun cryptophytes before ingestion (Sheng et al., 2009). Karlotoxins also have anti-grazing properties towards important microzooplankton and copepod grazers (Adolf et al., 2007; Waggett et al., 2008). Evidence suggests that fish kills because of $K$. veneficum, are caused indirectly by cell-rupture and toxin release upon contact with the gills (Place et al., 2008; Mooney et al., 2009), as opposed to the non-toxic heterotrophic dinoflagellate
Pseudopfiesteria shumwaye that may kill fish larvae by active tube-feeding (Vogelbein et al., 2002).

K. armiger is much less studied than $K$. veneficum (Daugbjerg et al., 2000; Bergholtz et al., 2005), and Karlotoxin production has not been reported in any strains of $K$. armiger. The species has been reported to produce a different substance with neurotoxic activity (Garcés et al., 2006), but the specific toxin has not been isolated and chemically characterised. While $K$. veneficum seems to prefer cryptophytes as food (Li et al., 1999; Adolf et al., 2008), K. armiger ingests most types of unicellular prey offered. It displays pronounced swarming behaviour and forms feeding aggregates when fed algal prey, allowing ingestion of prey several times larger than itself (Berge et al., 2008a). We studied if a strain of $K$. armiger and four strains of $K$. veneficum attacked and ingested copepods. We also describe the interactions observed via light microscopy and report the effects of an ecologically relevant range of $K$. armiger cell densities on the trophic flow between the mixotrophic microalgae and copepods in more detail.

\section{Materials and methods}

Microalgal strains and copepod culture

Monocultures of $K$. armiger (strain K-0668) and $K$. veneficum (strain K-1640) were obtained from the Scandinavian Culture Collection of Algae and Protozoa (SCCAP). The three other $K$. veneficum strains (K-1385, K-1635, K-1386) were isolated from NorthEast Atlantic locations (http://www.sccap.dk) and established during this work. All Karlodinium strains are available from SCCAP, except strain K-1386, which has been lost. The strain of $K$. armiger was the same as the one that was used to describe the species (Bergholtz et al., 2005). It was isolated from Alfacs Bay (Spain) during a harmful bloom event in 2000 and kindly submitted to SCCAP by Dr. Margarita Fernandéz-Tejedor. The microalgal stock cultures were grown in F/20 medium without silicate, based on sterile filtered seawater with a salinity of 30 . The same medium was used for the incubation experiments with the different Karlodinium strains and copepods (see below). The copepod Acartia tonsa originated from Denmark and was grown in gently aerated, large 80-l tanks, fed the cryptophyte Rhodomonas salina (strain K-0294, SCCAP) at saturating food conditions. The salinity in the copepod stock-culture tanks was 32 and the temperature was $20^{\circ} \mathrm{C}$.

As the detailed study of potential toxins involved was beyond the scope of this initial report, we did not measure toxin production in our strains. However, we tested whether the Karlodinium strains used were in a phagotrophic state under the provided experimental conditions (that is, mixotrophic and presumably toxic (Sheng et al., 2009)). We offered all five Karlodinium strains the cryptophyte Rhodomonas salina and the dinoflagellate Heterocapsa triquetra as food in predator:prey cell 
density ratios of $1: 5$ and $2: 5$, respectively. For determination of mixotrophic tendency or feeding frequencies $(\%$ cells containing visible food vacuoles), the strains were mixed in triplicate microwells (24-well plate, volume $2 \mathrm{ml}$ ) with the microalgal prey and fixed in glutaraldehyde $(1 \%$ final concentration) after $14 \mathrm{~h}$ of incubation under the same experimental conditions used throughout this study (see below). Feeding frequencies of the different Karlodinium strains were determined as the number of cells containing visible food vacuoles in the first 100 cells encountered, using an inverted microscope at 200-400 magnification.

\section{Experimental conditions}

The Karlodinium and microalgal prey cultures were adapted to the experimental light conditions $\left(70 \mu \mathrm{mol}\right.$ photons $\mathrm{m}^{2} \mathrm{~s}^{-1}$ in a light/dark cycle of $14: 10 \mathrm{~h}$ ) for at least 5 days of exponential growth before the experiments. Adaptation to experimental salinity (30) and temperature $\left(20^{\circ} \mathrm{C}\right)$ lasted at least 30 days, and F/20 medium was used (see above). One cohort of female Acartia tonsa was used in all experiments. Immobilisation and survival of copepods were observed via stereo and inverted microscopy. Immobilisation was recorded when the copepod was lying on the bottom of the microwell (containing from $2-15 \mathrm{ml}$ total culture/medium volume; see below) with erratic movements and without the ability to swim or jump, but with internal body movements still occurring, especially gut movements. Immobilisation caused the copepods to sink to the bottom of the microwells, where they were observed lying still but alive for many hours. Death was recorded when no internal gut movement occurred. At termination of the experiments (after 24-40 h), mixtures of microalgae and copepods were fixed in acid Lugol's solution. Microalgal cell concentrations were counted manually in acid Lugol's fixed samples using a Sedgewick

Table 1 Karlodinium strains used in the present study. Species, strain identification tag, mixotrophic tendency, cell densities used in copepod immobilisation and mortality experiment, whether or not the cultures caused mortality within $24 \mathrm{~h}$ and the strains showed swarming and accumulation behaviour towards a killed copepod (the copepods were killed using a needle and offered to Karlodinium cultures in multidish wells (24-well plate)). The strain ID refers to the Scandinavian Culture

Collection for Algae and Protozoa (www.sccap.dk). Y and N refer to yes and no, respectively.

\begin{tabular}{|c|c|c|c|c|c|}
\hline \multirow[t]{2}{*}{$\begin{array}{l}\text { Species/ } \\
\text { strain ID }\end{array}$} & \multicolumn{2}{|c|}{$\begin{array}{l}\text { Mixotrophic } \\
\text { tendency } \\
\text { (\% cells } \\
\text { containing } \\
\text { food } \\
\text { vacuoles) }\end{array}$} & \multirow[t]{2}{*}{$\begin{array}{c}\text { Concen- } \\
\text { tration in } \\
\text { Acartia tonsa } \\
\text { experiment } \\
\left(10^{4} \mathrm{cells} \mathrm{ml}^{-1}\right)\end{array}$} & \multirow[t]{2}{*}{$\begin{array}{c}\text { Acartia } \\
\text { tonsa } \\
24-h \\
\text { mortality }\end{array}$} & \multirow[t]{2}{*}{$\begin{array}{l}\text { Swar- } \\
\text { ming } \\
\text { beha- } \\
\text { viour }\end{array}$} \\
\hline & R. salina & H. triquetra & & & \\
\hline K. armiger K-0668 & 91 & 57 & 1.0 & $\mathrm{Y}$ & $\mathrm{Y}$ \\
\hline K. veneficum K-1385 & 0 & 0 & 2.5 & $\mathrm{~N}$ & $\mathrm{~N}$ \\
\hline K. veneficum K-1635 & 9 & 3 & 3.6 & $\mathrm{~N}$ & $\mathrm{~N}$ \\
\hline K. veneficum K-1640 & 7 & 3 & 5.0 & $\mathrm{~N}$ & $\mathrm{~N}$ \\
\hline K. veneficum K-1386 & 10 & 5 & 2.7 & $\mathrm{~N}$ & $\mathrm{~N}$ \\
\hline
\end{tabular}

Rafter chamber (Graticules Ltd, Tonbridge, UK), and at least 300 cells were counted. To estimate copepod production during the incubation period we counted the number of eggs, empty egg-shells and nauplius larvae at the end of the incubation period (24-40 h). To estimate copepod grazing, we counted the number of faecal pellets produced during the incubation period.

Effect on copepod motility and mortality of strains of $\mathrm{K}$. veneficum and $\mathrm{K}$. armiger

To study potential immobilisation and mortality effects of four strains of $K$. veneficum and one strain of $K$. armiger on copepods, we incubated two adult Acartia tonsa females in five replicate 24-plate microwells containing $2 \mathrm{ml}$ of dense Karlodinium spp. cultures $\left(>10000\right.$ cells $\mathrm{ml}^{-1}$ ) (Table 1). The densities used represent commonly occurring Karlodinium bloom densities (blooms are often $<10000$ cells $\mathrm{ml}^{-1}$ and sometimes 100000 cells $\mathrm{ml}^{-1}$ ) (Garcés et al., 2006; Place et al., 2012). As control copepod treatments, we included copepods fed 20000 cells $\mathrm{ml}^{-1}$ of an unidentified phototrophic gymnodinoid dinoflagellate (North-East Atlantic origin; strain ID unavailable) and the cryptophyte Rhodomonas salina. We also included a starved copepod control treatment without food in fresh medium. Additionally, to study potential involvement of extracellular toxins that leaked into the water, we included a treatment of cell-free culture filtrate of the live $K$. armiger culture $\left(10000\right.$ cells $\left.\mathrm{ml}^{-1}\right)$. The cell-free culture filtrate was prepared by gently filtering the culture through $5 \mu \mathrm{m}$ membrane filters (Poretics, Livermore, CA, USA) at a very low pressure $<15 \mathrm{~cm} \mathrm{Hg}$ vac and the filter did not dry during this filtration, but was always covered by the culture medium. This was done to avoid potential physical disruption of cells and release of toxins. The copepods were starved for 2 days before setting up the experiment. For the initial $130 \mathrm{~min}$, we observed copepod motility in all the treatments every 5-30 min, and recorded motility and mortality after $24 \mathrm{~h}$. Copepod grazing (that is, number of faecal pellets produced) was recorded in the control treatments, the culture filtrate treatment and the $K$. armiger live cells treatment.

\section{Ability to immobilise and ingest other marine metazoans}

Because of the absence of attacks on copepods in four out of five investigated Karlodinium strains, the rest of the incubations were only done for $K$. armiger (strain K-0688). To study if $K$. armiger immobilise and kill other metazoan organisms, seawater samples (2l) were brought to the laboratory and a subsample was gently filtered through a $100-\mu \mathrm{m}$ net to concentrate the organisms (the organisms were covered in water during filtration to avoid physical stress). An adult nematode, a trochophore and a later-stage polychaete larva were isolated and 
transferred to multidish wells, containing $K$. armiger cells at densities of 1000-2000 cells ml ${ }^{-1}$, and observed using an inverted microscope connected to a video-camera.

Acartia tonsa immobilisation and survival, and trophic roles of microalgae and copepods in a range of

$\mathrm{K}$. armiger cell densities

The relationship between $K$. armiger cell density and copepod immobilisation, mortality, grazing and reproduction was also investigated. We exposed adult female Acartia tonsa to a range of cell densities in six-plate microwells. Five copepods were added in each microwell containing $15 \mathrm{ml}$ of culture or F/20 medium (control) in three replicate units. K. armiger cell densities were, 0, 400, 1100, 3500,5000 and 7300 cells $\mathrm{ml}^{-1}$. The range was chose as these densities represent naturally occurring bloom densities of $K$. armiger (Delgado and Alcaraz, 1999; Fernandez-Tejedor et al., 2004; Garcés et al., 2006). Using a stereomicroscope and an inverted microscope, we recorded the number of immobile and dead copepods every $1-12 \mathrm{~h}$ for up to 2 days. We also measured copepod grazing (number of faecal pellet produced) and copepod reproduction (number of eggs and nauplii produced) in the different $K$. armiger cell density treatments.

At a density of $3500 \mathrm{~K}$. armiger cells $\mathrm{ml}^{-1}$, we compared the population growth rate of $K$. armiger with the growth in cultures without copepods, by measuring the increase in cell density over the 2 days incubation. For comparison, K. armiger cells in mono-culture were grown under identical light conditions (see above) as in the copepod treatment.

\section{Calculations}

Mortality and immobilisation was calculated in the microwells containing two or five copepods each, as the averaged percentage of dead and immobile copepods observed in the 3-5 replicate units (see above). Copepod production and grazing rates were calculated as the change in numbers of eggs and nauplius larvae and faecal pellets, respectively, divided by the length of incubation period, or expressed as numbers produced during the incubation period. Exponential growth rates of the $K$. armiger were calculated according to, $\mu=\left(\ln x_{t_{2}}\right.$ $\left.\ln x_{t_{1}}\right) /\left(t_{2}-t_{1}\right)$, where $x_{\mathrm{t}_{2}}$ and $x_{\mathrm{t}_{1}}$ is the cell concentration at end (time $=t_{2}$ ) and start (time $\left.=t_{1}\right)$ of the sampling interval, respectively. Cell densities were taken from three replicate units. Difference in growth rate between the cultures (3500 cells $\mathrm{ml}^{-1}$ ) with and without copepods was tested using a $t$-test and evaluated at a significance level of 0.05 .

\section{Results and discussion}

Effects on copepod motility and survival of strains of $\mathrm{K}$. veneficum and $\mathrm{K}$. armiger

In the cultures with live $K$. armiger cells $\left(10000\right.$ cells $\left.\mathrm{ml}^{-1}\right)$, half of the copepods were immobilised within only $1 \mathrm{~h}$, and nearly all were unable to swim or perform escape jumps after 135 min (Figure 1a). We observed no effects on the motility of Acartia tonsa in high-density cultures of any of the four $K$. veneficum strains, and the copepods were healthy and swam normally after the $24 \mathrm{~h}$ incubation in these treatments (Figures 1a and b; densities from 25000-50000 cells ml ${ }^{-1}$; Table 1). Both starved and fed control copepods (fed an unidentified gymnodinoid phototrophic dinoflagellate and the cryptophyte Rhodomonas salina) were all alive and healthy after $24 \mathrm{~h}$, while all copepods in the treatment with $K$. armiger (10000 cells $\mathrm{ml}^{-1}$ ) were dead (Figure 1b) and covered with dinoflagellates tube feeding on the carcasses. The copepods grazed and produced faecal pellets in the fed control treatments (Figure 1c). No pellets were produced in the starved control or in the cell-free K. armiger culture filtrate, but starvation did not cause mortality or affected the motility of the copepods (Figures 1a and b).

The lack of motility and mortality effects after $24 \mathrm{~h}$ of the cell-free $K$. armiger culture filtrate of the same culture that caused $100 \%$ mortality (10 000 cells $\mathrm{ml}^{-1}$ ), suggests that direct cell-contact by live $K$. armiger cells is required for copepod immobilisation and mortality to occur (Figures 1a and b). Previous studies involving harmful dinoflagellates and metazoan mortality have also reported that effects require direct contact with live cells; for example, Heterocapsa circularisquama caused mortality of bivalve larvae and rotifers (Nagai et al., 1996) and Cochlodiinium polykrikoides caused rapid mortality of diverse species of bivalve larvae, only by direct cell-contact (Tang and Gobler, 2009). Similarly, natural bloom populations containing both $K$. armiger and $K$. veneficum (Garcés et al., 2006) studied in the laboratory by Delgado and Alcaraz (1999) also required live cells to cause immobilisation and mortality of the copepod Acartia granii. These authors suggested a paralytic toxin as the cause and showed scanning electron microscopy of the affected copepods with attached microalgal cells. The possibility of microalgal feeding on the copepods as the cause of mortality was not discussed, probably because the causative organisms were putatively identified as Gyrodinium corsicum and thought to be entirely phototrophic. However, all the cells in their micrographs were facing the copepod with the ventral parts where the feeding tube emerges (Delgado and Alcaraz, 1999).

The fact that none of the $K$. veneficum strains tested here attacked Acartia tonsa agrees well with previous experimental studies on other toxic strains of this species, reporting no short-term $(<48 \mathrm{~h})$ motility and mortality effects on different species of copepods in high-density cultures (Waggett et al., 2008; da Costa, Fernandez 2002; da Costa et al., 2005; Vaque et al., 2006). However, strain variation in cell quotas and types of Karlotoxins 


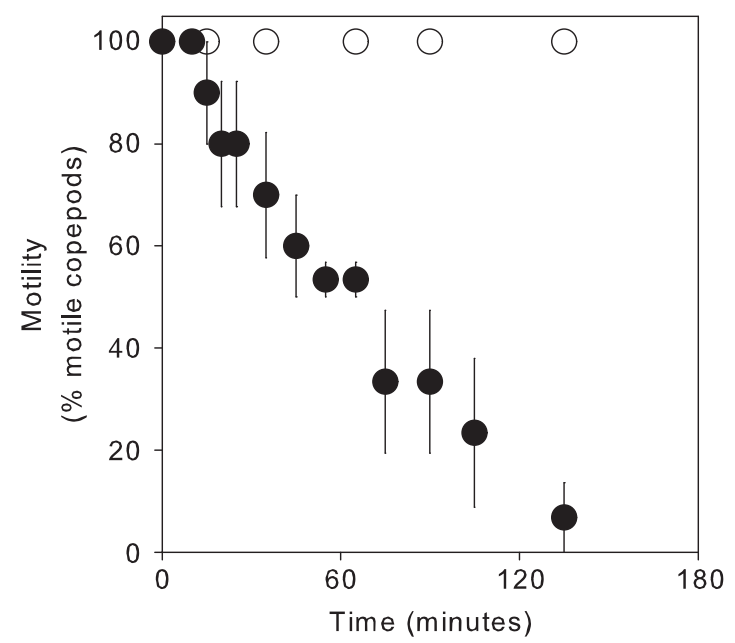

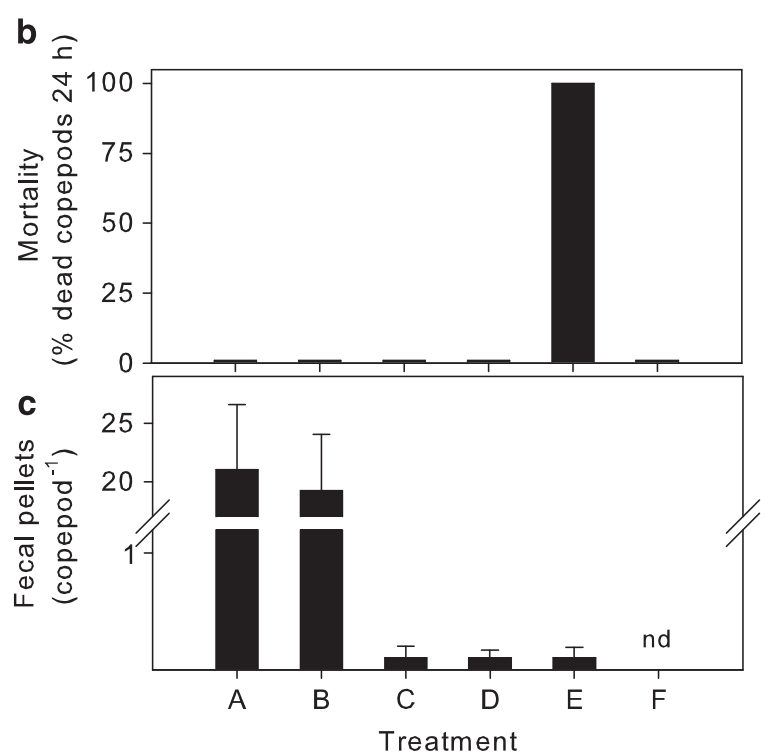

Figure 1 Effects on copepod motility and mortality of $K$. veneficum and $K$. armiger strains and control treatments. (a) Short-term immobilisation in treatments with four $K$. veneficum strains (white circles) and with one $K$. armiger strain (black circles). White circle also includes data from all copepod control treatments, that is, with and without microalgal food and cell-free $K$. armiger culture filtrate (10000 cells ml ${ }^{-1}$ ); (b) Mortality and; (c) grazing of adult female copepods incubated in treatments: (A) Rhodomonas salina (ca. 20000 cells ml ${ }^{-1}$ ), (B) and unidentified gymnodinoid dinoflagellate (ca. 20000 cells ml $^{-1}$ ), (C) without food (unfed control), (D) in the cell-free $K$. armiger culture filtrate of the (E) live $K$. armiger cell treatment $\left(10000 \mathrm{cells} \mathrm{ml}^{-1}\right.$ ) and (F) all four $K$. veneficum strains (See Table 1 for cell densities). Data in (a, b) represent means of five replicate units containing two copepods each and error bars indicate standard error s.e. $(n=5)$. (nd) indicate that the data for faecal pellet production were not determined in the treatments with $K$. veneficum strains.

is extensive in K. veneficum (Bachvaroff et al., 2009). Some strains are non-toxic and these seem to be unable to catch and feed on microalgal prey and are therefore primarily phototrophic (Sheng et al., 2009; Place et al., 2011). Although, we did not investigate toxin production in our strains, three of the four $K$. veneficum strains were able to feed on both types of microalgal prey offered under the experimental conditions provided. This indicates that our three $K$. veneficum strains were probably toxic. Further studies of the presence, types and cell quotas of Karlotoxins are needed to confirm this assumption.

The lack of copepod attacks by $K$. veneficum strains may also be linked to the relatively low mixotrophic tendencies observed under the experimental conditions provided (Table 1). Toxicity of $K$. veneficum strains has been found to vary according to salinity, temperature and nutrient limitation (Adolf et al., 2009; Place et al., 2011). Also the balance between heterotrophy and phototrophy varies significantly as functions of light intensity, prey concentration and nutrient concentrations (Li et al., 1999; Adolf et al., 2006; Place et al., 2011). The mixotrophic tendency, in terms of $\%$ cells containing food vacuoles, was much higher in the $K$. armiger strain than in any of the $K$. veneficum strains when fed microalgal prey (Table 1). Therefore we cannot reject the possibility that some strains or natural populations of $K$. veneficum may be triggered to attack copepods under other environmental conditions. In fact, $K$. veneficum was recently reported to attempt feeding on Acartia tonsa from field observations (USA), although conclusive evidence was not provided (Place et al., 2011). Our field observation of tube feeding on a nauplius larva (Figure 2a; Supplementary Video S1), also support that feeding on copepods takes place in other species.

Interactions between $\mathrm{K}$. armiger, copepods and other metazoans observed in the microscope

We directly observed copepod immobilisation by $K$. armiger (Figure 2b) using an inverted microscope. These observations confirmed the importance of direct cell-contact to cause immobilisation and mortality. Shortly after adding the copepods into the $K$. armiger culture, the cells were attracted to the copepods (Figure 2c), and frequently attached to them facing the metazoan with their ventral side (Supplementary Video S2). Initially, several cellcopepod contacts seemed to be directed towards the innervated first antennae (Figure 2d) and the urosome or telson (Supplementary Video S2), which are involved in copepod motility and sensing. Copepods sense hydrodynamical disturbances caused by predators and prey in the surrounding fluid with hairs and setae situated at their pair of first antennae and the telson (Strickler and Bal, 1973; Kiørboe and Visser, 1999). Depending on the swimming speed and size of an encountering organism, copepods can respond to predators by performing powerful escape jumps (Kiørboe and Visser, 1999). The microscopic size of $K$. armiger may disguise it as a prey and enable the predator to 

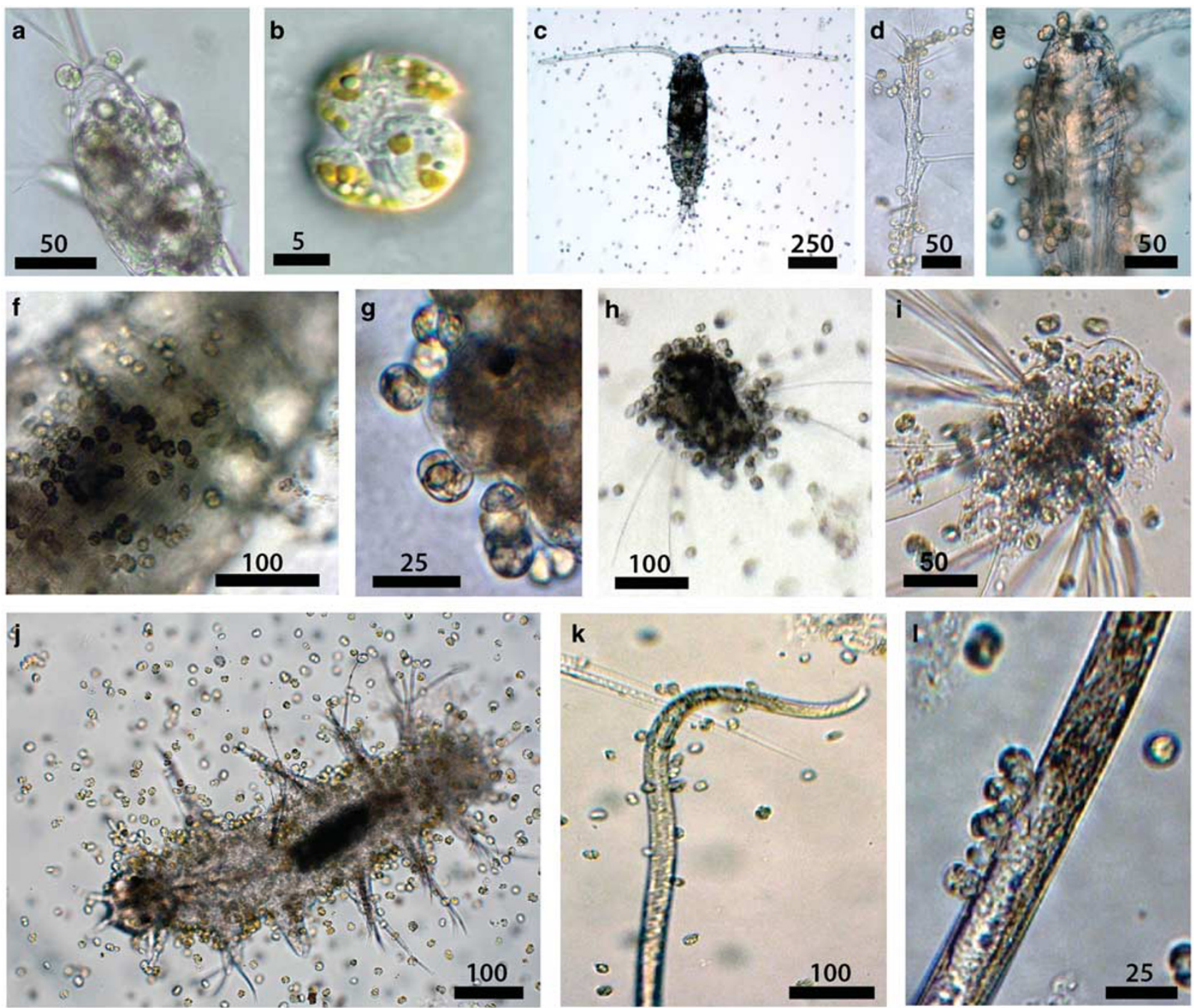

Figure 2 Microalgae immobilising and eating metazooplankton. (a) Frame grabbed micrographs of an unidentified microalgal dinoflagellate tube feeding on an immobilised copepod nauplius larvae in a natural seawater sample from Denmark; (b) Micrograph of $K$. armiger in ventral view (type material). Note many small yellow-green chloroplasts (1-2 $\mu \mathrm{m}$ long); (c) Frame grabbed micrograph of the common marine copepod Acartia tonsa mixed with a culture of $K$. armiger; (d) Frame grabbed micrographs of initial microalgal attacks on the sensory antennae of the copepod (compound image); (e) K. armiger cells swarming around and attaching to an immobilised copepod; (f) Accumulations of feeding $K$. armiger cells on the surface of A. tonsa; (g) Tube feeding on an unidentified planktonic polychaete trochophore larva of $K$. armiger. Note the large food vacuole as dark globules in the central part of $K$. armiger; (h) $K$. armiger immobilising and; (i) food remnants of the trochophore larva after a day of incubation. A substantial part was removed by tube feeding; (j) K. armiger swarming around and forming feeding aggregates on an immobilised later stage polychaete-larva; (k) K. armiger attacking and attaching; (l) to an unidentified marine nematode. Units on scale bars $\mu \mathrm{m}$. Video sequences can be viewed as Supplementary Information on The ISME Journal website (http://www.nature.com/ismej).

attack the copepod unnoticed. The attacks on Acartia tonsa resulted in erratic cramp-like movements and inability to swim (Supplementary Video S2). This suggests that a fast-acting paralytic toxin is transferred directly into the nervous system. Potential toxin transfer could be brought about by the numerous extrusosomes covering the cell surface of $K$. armiger (Bergholtz et al., 2005) or through the feeding tube itself.

The effect of $K$. armiger attacks on the copepods was very fast, and the first immobilised individual was observed within minutes (Figure 1a, Supplementary Video S2). After some time the microalgae swarmed more aggressively, accumulated and collectively fed on the immobilised but still live copepods (Figures 2e and f) (gut movements still occurring). Finally, this collective feeding resulted in the death of the copepod (Supplementary Video S3). The ligaments between copepod carapace segments seemed to be preferential zones for initial food uptake by the microalgae (Figure 2f). This may be related to the capacity of the feeding tube to penetrate the exoskeleton. Feeding on other microalgae, K. armiger has difficulties ingesting heavily armoured dinoflagellate prey, such as species of Alexandrium, and is hardly able to ingest diatoms with tough silica cell 
coverings (Berge et al., 2008a). A single tube feeding event on the copepod lasted from seconds to several minutes and a $K$. armiger cell was able to feed several times. After 2 days of incubation with Acartia tonsa, the microalgal population had ingested almost all of the copepod body tissue (Supplementary Video S3). Food uptake resulted in the formation of different sized food vacuoles and substantial cell swelling (a large food vacuole is shown in Figure 2g). When $K$. armiger feeds on microalgal prey, it can increase its cell volume to more than five times its original cell volume (Berge et al., 2008a).

We inoculated an adult nematode, a polychaete trochophore and a later stage polychaete-larva in cultures of $K$. armiger (1000-2000 cells $\mathrm{ml}^{-1}$ ), to investigate if the carnivorous behaviour only affected the copepod Acartia tonsa. All metazoans offered were attacked and immobilised within hours (Figures 2g-l, Supplementary Video S4).The entire body content of the trochophore larvae was nearly removed by tube feeding within $24 \mathrm{~h}$ (Figure 2i, Supplementary Video S4). Feeding on the nematode was not directly observed, but the $K$. armiger cells were clearly attached to it and attempted to penetrate the cuticle with the feeding tube (Figure 2l).

The swarming behaviour of $K$. armiger toward metazoans was most likely by chemotaxis (Supplementary Video S3-S4), and similar swarming behaviour was reported when $K$. armiger fed on microalgae (Berge et al., 2008a). Chemotaxis has also been reported in primarily heterotrophic dinoflagellates (Spero, 1985; Schnepf and Drebes, 1986); for example, the tube feeding freshwater species Peridiniopsis berolinensis ingesting tissue of an injured nematode (Calado and Moestrup, 1997) and the marine Pseudopfiesteria shumwayae tube feeding on fish larvae (Vogelbein et al., 2002).

\section{Effect of $\mathrm{K}$. armiger densities on the trophic interactions between microalgae and copepods} Copepod immobilisation, mortality, grazing and reproduction depended on $K$. armiger cell densities in a dose-response manner (Figures 3a-d). At cell densities over 3500 cells ml $^{-1}, 50 \%$ of the copepods
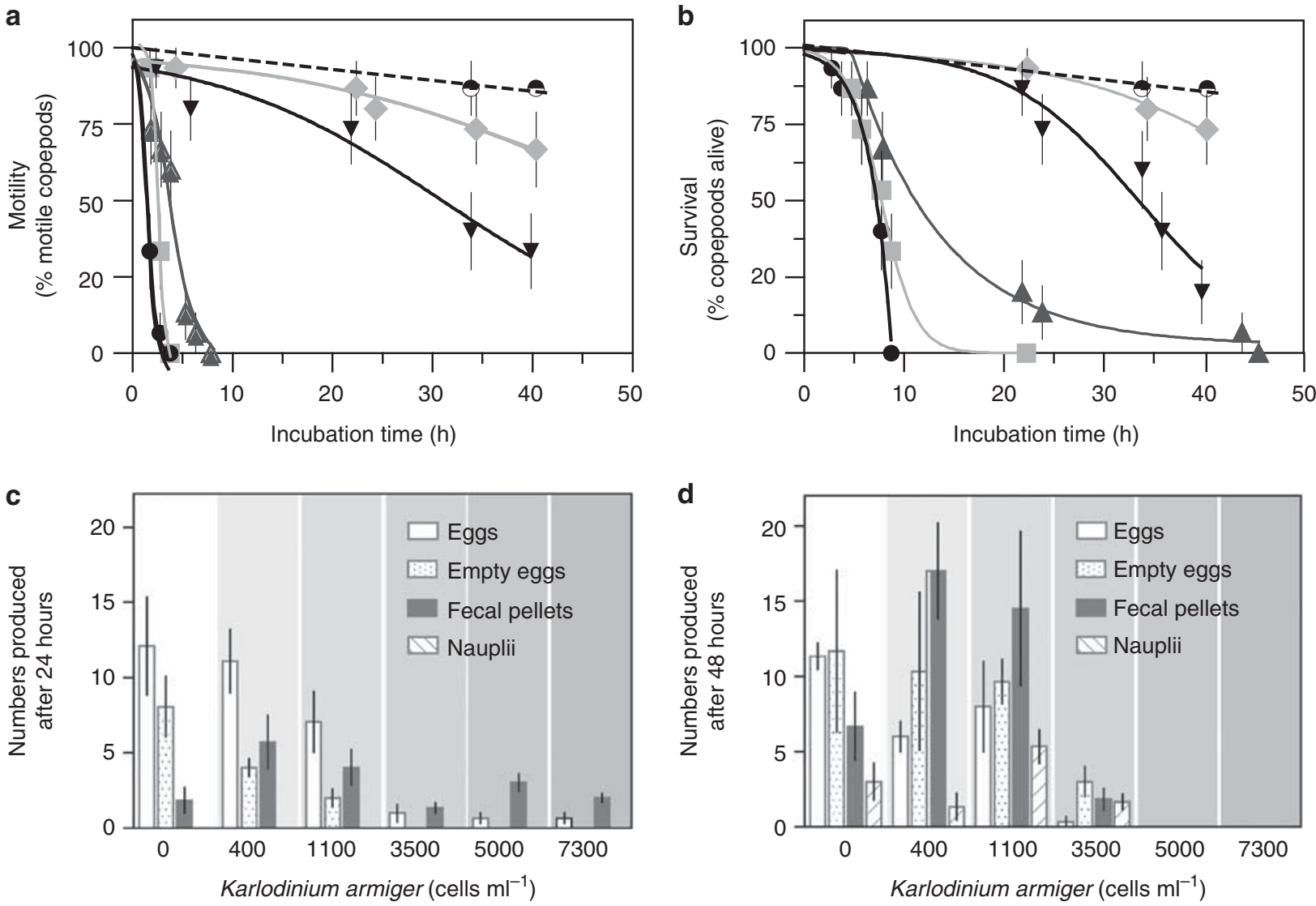

Figure 3 Immobilisation and survival of Acartia tonsa, and trophic roles of microalgae and copepods in a range of $K$. armiger cell densities. (a) copepod immobilisation and; (b) survival as a function of time when incubated with different $K$. armiger cell densities of 0 (black and white divided circles), 400 (grey tilted squares), 1100 (black triangles), 3500 (dark grey triangles), 5000 (grey squares) and 7300 cells $\mathrm{ml}^{-1}$ (black circles); (c, d) number of copepod faecal pellets, eggs, empty egg-shells and nauplii larvae produced after $24 \mathrm{~h}$ (c) and $48 \mathrm{~h}$ (d) of incubation with different densities of $K$. armiger. Visual gradient in (c, d), indicate microalgal density. Suppressed grazing (faecal pellets) and production (eggs and nauplius larvae) of the copepods are occurring at cell densities $>1100$ cells ml ${ }^{-1}$, while K. armiger is grazed by Acartia tonsa at densities $<1100$ cells $\mathrm{ml}^{-1}$. Data points represent means of three replicate units containing five copepods each, and error bars indicate s.e. $(n=3)$. 


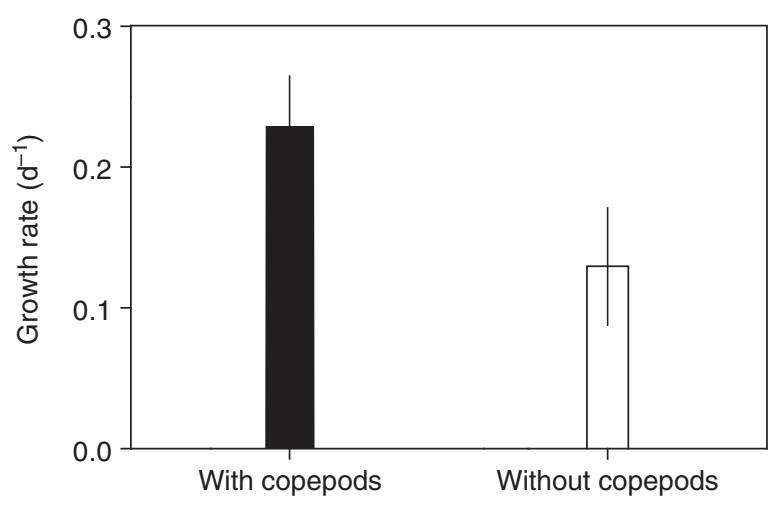

Figure 4 Growth in $K$. armiger culture with and without copepods. Growth rate $\left(\mathrm{d}^{-1}\right)$ measured during incubation with copepods (black bar) as potential food was $85 \%$ higher than purely phototrophic growth rates without copepods (white bar) $(t$-test, $P>0.05)$. Growth rate was calculated as the change in logtransformed cell density divided by the incubation time. Bars represent means of three replicates and error bars are s.e. $(n=3)$.

were immobilised within $2 \mathrm{~h}$ of exposure (Figure 3a), and after ca. $8 \mathrm{~h}, 50 \%$ of the copepods were dead (Figure 3b). At densities below 1100 cells $\mathrm{ml}^{-1}$, the copepods grazed and reproduced on a diet of $K$. armiger, but above 3500 cells $\mathrm{ml}^{-1}$, copepod grazing and egg-production were suppressed (Figures 3c and d). The number of nauplius larvae, eggs and faecal pellets produced in the lower $K$. armiger densities, were lower after $40 \mathrm{~h}$ than after $24 \mathrm{~h}$ (Figures 3c and d). This suggests that $K$. armiger also ingested copepod eggs and faecal pellets (Supplementary Video S5). Ingestion of copepod faecal pellets by $K$. armiger and other phagotrophic dinoflagellates has recently been reported (Poulsen et al., 2011).

Our data show that the trophic roles of $K$. armiger as prey and copepods as consumers are switched, when densities of the mixotrophic microalgae reach

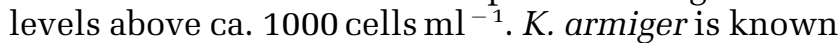
to occur at higher cell densities in eutrophic estuarine waters (Fernandez-Tejedor et al., 2004; Garcés et al., 2006). Field studies have reported maximum densities in the range 10000-100000 cells $\mathrm{ml}^{-1}$ (Delgado and Alcaraz, 1999; Deeds et al., 2002) for $K$. armiger and $K$. veneficum. This indicates that microalgal feeding on copepods and other metazoans can occur in coastal areas.

The carnivorous strategy of $K$. armiger on copepods is likely to be an important mechanism when high cell densities have developed, coupling population growth to reduced grazing and promoting the persistence of blooms. It may be less important during the initiation of blooms at lower cell densities, but $K$. armiger may also benefit from food uptake of other metazooplankton organisms at lower cell densities without being able of immobilisation. This is because, although $K$. armiger harbours permanent chloroplast and is unable to survive without light, its growth rate is very low when growing entirely phototrophic $\left(<0.1 \mathrm{day}^{-1}\right)$. Fast growth rates (0.5-0.7 day ${ }^{-1}$ ) are only obtained when ingesting prey under mixotrophic growth. As feeding seems to stimulate the photosynthetic machinery of this mixotroph (possibly by acquiring essential growth factors), only small volumes of food may be required to significantly increase the growth rate (Berge et al., 2008a, b). In the treatment with 3500 cells $\mathrm{ml}^{-1}$ of the density experiment, the presence of copepods resulted in $85 \%$ higher population growth rate of $K$. armiger, compared with the phototrophic growth rate in monocultures without copepods (Figure 4). This shows that ingestion of metazoan tissue may also supply the growth factors necessary for faster growth in K. armiger. Thus, by feeding on live individuals with no immobilisation and mortality effects on the metazoan population as a whole, $K$. armiger may obtain increased growth rates and therefore also benefit during bloom initiation at lower cell densities.

Toxicity, prey selection and specificity

Although we did not measure toxin production in any of our tested strains, our direct observations of the interactions between $K$. armiger and different metazoans via microscopy, combined with the data on timescales of copepod immobilisation (within minutes) and the density-dependent immobilisation and mortality (dose-response relation) strongly support the involvement of a potent neurotoxin in this species. Thus, $K$. armiger seems to use toxins to stun and feed on prey in a similar manner to $K$. veneficum preying on cryptophytes (Sheng et al., 2009), but that the range of prey types extends to diverse metazoan organisms. This difference in prey specificity may indicate that the activity of the toxins produced by $K$. armiger differ from the well-known Karlotoxins produced by K. veneficum (Deeds et al., 2002; Mooney et al., 2009; Sheng et al., 2009). Karlotoxin specificity has been shown to be related to the sterol composition of cell membranes (Deeds et al., 2002). While most studies involving strains of $K$. veneficum have involved cryptophytes as food, recent reports suggest that the species is able to switch to other types of prey such as diatoms (Place et al., 2011). In our study, mixotrophic $K$. veneficum strains ingested both cryptophytes and thecate dinoflagellates (Table 1). These observations suggests that prey specificity may be more general in $K$. veneficum than previously recognised.

The trophic roles of the omnivorous tube feeding $K$. armiger are multiple; it may simultaneously act as a primary producers, grazer of microalgal food, a predator of unicellular (Berge et al., 2008a) and metazoan zooplankton and as a detritivore on faecal pellets (Poulsen et al., 2011). This feeding flexibility indicates that $K$. armiger competes for resources with organisms at several different trophic levels in the marine food web. Prey selection and prey preference by $K$. armiger in natural communities may affect 
metazoan food web structure and function. The efficiency of ingestion by $K$. armiger feeding on phytoplankton species has been shown to be highly dependent on the food quality of the prey and ingestion rates are lower when fed armoured compared with unarmoured microalgal prey (Berge et al., 2008b). Copepods have rigid exoskeletons, which may increase prey-handling time (that is, time taken for immobilisation and piercing the prey). Thus, harmful effects of blooms of $K$. armiger on more easily handled organisms (for example, unarmoured planktonic larvae) may occur at even lower cell densities than reported here for Acartia tonsa. Support for this comes from an apparent higher sensitivity towards natural bloom populations containing $K$. armiger of two species of finfish compared with the copepod Acartia grani (Delgado and Alcaraz, 1999; Fernandez-Tejedor et al., 2004). In these studies, paralysis of juvenile finfish $(2-5 \mathrm{~cm}$ in length) occurred within $2 \mathrm{~min}$, and the fishes displayed erratic movements and loss of equilibrium and lethargy (Fernandez-Tejedor et al., 2004).

\section{Conclusions}

Four strains of $K$. veneficum (three of these were mixotrophic) tested did not attack and feed on the copepod Acartia tonsa. However, K. armiger (strain K-0688) was able to paralyse metazoan prey and feed on them when the dinoflagellate occurred

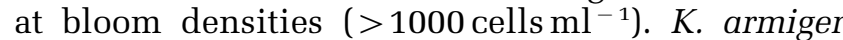
thus represents the first example of mixotrophic microalgae that attack and eat live metazoans (Hansen and Calado, 1999; Jeong et al., 2010), and obtain increased growth rate from it. The strategy seems to be accomplished by means of collective swarming behaviour (chemotaxis) and the involvement of a potent but unknown neurotoxin. Following paralysis, feeding aggregates of $K$. armiger cells accumulated on the metazoan body. K. armiger may turn the food web upside down and release topdown control by immobilising and feeding on important copepod grazers. Most importantly, $K$. armiger ingests different types of metazooplankton organisms, suggesting that it may attack and feed on several different types of metazooplankton organisms, including larvae of commercially important bivalves and finfish. Future studies on the chemical structure and properties of the toxins produced by $K$. armiger may provide valuable new insights into the type of organisms that are potentially vulnerable. Occurrence of similar carnivorous behaviour by other harmful species and especially strains of $K$. veneficum need more attention.

\section{Acknowledgements}

TB and MM were supported by $\mathrm{PhD}$ grants from the Faculty of Science, University of Copenhagen, Denmark and LKP was supported by The Carlsberg Foundation, grant no. 2007-01-0495. We thank two anonymous referees whose comments and suggestions significantly improved this manuscript. TB thanks Bente Aaberg Voigt for financial support. ND thanks the Carlsberg and Villum Kann Rasmussen foundations for equipment grants. PJH was supported by the Danish Agency for Science and Technology, grant no. 2101-07-0086. We thank Julie Rindung for assistance with graphical presentation and Tom Fenchel for critically reading and commenting on an earlier version of the manuscript. We also thank Gert Hansen at the Scandinavian Culture Collection for Algae and Protozoa (SCCAP) for providing and receiving culture strains used in the present study.

\section{References}

Adolf JE, Bachvaroff T, Place AR. (2008). Can cryptophyte abundance trigger toxic Karlodinium veneficum blooms in eutrophic estuaries? Harmful Algae 8: 119-128.

Adolf JE, Krupatkina D, Bachvaroff T, Place AR. (2007). Karlotoxin mediates grazing by Oxyrrhis marina on strains of Karlodinium veneficum. Harmful Algae 6: $400-412$.

Adolf JE, Stoecker DK, Harding LW. (2006). The balance of autotrophy and heterotrophy during mixotrophic growth of Karlodinium micrum (Dinophyceae) J Plankton Res 28: 737-751.

Adolf JE, Bachvaroff T, Place AR. (2009). Environmental modulation of karlotoxin levels in strains of the cosmopolitan dinoflagellate, Karlodinium veneficum. J Phycol 45: 176-192.

Armbrust EV. (2009). The life of diatoms in the world's oceans. Nature 459: 185-192.

Bachvaroff T, Adolf JE, Place AR. (2009). Strain variation in Karlodinium veneficum (Dinophyceae): toxin profiles, pigments, and growth characteristics J Phycol 45: 138-153.

Berge T, Hansen PJ, Moestrup Ø. (2008a). Feeding mechanism, prey specificity and growth in light and dark of the plastidic dinoflagellate Karlodinium armiger. Aquat Microb Ecol 50: 279-288.

Berge T, Hansen PJ, Moestrup Ø. (2008b). Prey size spectrum and bioenergetics of the mixotrophic dinoflagellate Karlodinium armiger. Aquat Microb Ecol 50: 289-299.

Bergholtz T, Daugbjerg N, Moestrup Ø. (2005). On the identity of Karlodinium veneficum and description of Karlodinium armiger sp. nov. (Dinophyceae), based on light and electron microscopy, nuclear-encoded LSU rDNA, and pigment composition. J Phycol 42: 170-193.

Braarud T. (1957). A red water organism from Walvis Bay. Galathea Rep 1: 137-138.

Burkholder JM, Glasgow HB. (1997). Pfiesteria piscicida and other Pfiesteria-like dinoflagellates: behavior, impacts, and environmental controls. Limnol Oceanogr 42: 1052-1075.

Burkholder JM, Glibert PM, Skelton HM. (2008). Mixotrophy, a major mode of nutrition for harmful algal species in eutrophic waters. Harmful Algae 8: 77-93.

Calado AJ, Moestrup Ø. (1997). Feeding in Peridiniopsis berolinensis (Dinophyceae): new observations on tube feeding by an omnivorous, heterotrophic dinoflagellate. Phycologia 36: 47-59. 
Calbet A, Bertos M, Fuentes-Grunewald C, Alacid E, Figueroa R, Renom B et al. (2011). Intraspecific variability in Karlodinium veneficum: growth rates, mixotrophy, and lipid composition. Harmful Algae 10: 654-667.

da Costa RM, Fernandez F. (2002). Feeding and survival rates of the copepods Euterpina acutifrons Dana and Acartia grani Sars on the dinoflagellates Alexandrium minutum Balech and Gyrodinium corsicum Paulmier and the Chryptophyta Rhodomonas baltica Karsten J Exp Mar Biol Ecol 273: 131-142.

da Costa RM, Franco J, Cacho E, Fernández F. (2005). Toxin content and toxic effects of the dinoflagellate Gyrodinium corsicum (Paulmier) on the ingestion and survival rates of the copepods Acartia grani and Euterpina acutifrons. J Exp Mar Biol Ecol 322: 177-183.

Daugbjerg N, Hansen G, Larsen J, Moestrup Ø. (2000). Phylogeny of some major genera of dinoflagellates based on ultrastructure and partial LSU rDNA sequence data, including the erection of 3 new genera of unarmoured dinoflagellates. Phycologia 39: 302-317.

de Salas MF, Bolch CJ, Hallegraeff GM. (2005). Karlodinium australe sp. nov. (Gymnodiniales, Dinophyceae), a new potentially ichthyotoxic unarmoured dinoflagellate from lagoonal habitats of south-eastern Australia. Phycologia 44: 640-650.

Deeds JR, Terlizzi DE, Adolf JE, Stoecker DK, Place AR. (2002). Toxic activity from cultures of Karlodinium micrum (=Gyrodinium galatheanum) (Dinophyceae)—a dinoflagellate associated with fish mortalities in an estuarine aquaculture facility. Harmful Algae 1: 169-189.

Delgado M, Alcaraz M.. (1999). Interactions between red tide microalgae and herbivorous zooplankton: the noxious effects of Gyrodinium corsicum (Dinophyceae) on Acartia grani (Copepoda: Calanoida) J Plankton Res 21: 2361-2372.

Fernandez-Tejedor M, Soubrier-Pedreno MA, Furones MD. (2004). Acute $\mathrm{LD}_{50}$ of a Gyrodinium corsicum natural population for Sparus aurata and Dicentrarchus labrax. Harmful Algae 3: 1-9.

Garcés E, Fernandez M, Penna A, Van Lenning K, Gutierrez A et al. (2006). Characterization of NW Mediterranean Karlodinium spp. (Dinophyceae) strains using morphological, molecular, chemical and physiological methodologies. $J$ Phycol 42: 1096-1112.

Hansen PJ, Calado AJ. (1999). Phagotrophic mechanisms and prey selection in free-living dinoflagellates I Eurkaryot Microbio 146: 382-389.

Hansen PJ. (2011). The role of photosynthesis and food uptake for the growth of mixotrophic dinoflagellates J Eukaryot Microbiol 58: 203-214.

Jakobsen HH, Hansen PJ, Larsen J. (2000). Growth and grazing responses of two chloroplast-retaining dinoflagellates: effect of irradiance and prey species. Mar Ecol Prog Ser 201: 121-128.

Jeong HJ, Yoo YD, Kim JS, Seong KA, Kang NS, Kim TH. (2010). Growth, feeding and ecological roles of the mixotrophic and heterotrophic dinoflagellates in marine planktonic food webs. Ocean Science Journal 45: $65-91$.

Jones RI. (1994). Mixotrophy in planktonic protists as a spectrum of nutritional strategies. Marine Microbial Food Webs 8: 87-96.
Kiørboe T, Visser A. (1999). Predator and prey perception in copepods due to hydromechanical signals. Mar Ecol Prog Ser 179: 81-95.

Lewitus AJ, Glasgow HB, Burkholder JM. (1999). Kleptoplastidy in the toxic dinoflagellate Pfiesteria piscicida (Dinophyceae). J Phycol 35: 303-312.

Li AS, Stoecker DK, Adolf JE. (1999). Feeding, pigmentation, photosynthesis and growth of the mixotrophic dinoflagellate Gyrodinium galatheanum. Aquat Microb Ecol 19: 163-176.

Mooney BD, de Salas M, Hallegraeff GM, Place AR. (2009). Survey for karlotoxin production in 15 species of gymnodinioid dinoflagellates (Kareniaceae, Dinophyta). J Phycol 45: 164-175.

Nagai K, Matsuyama Y, Uchida T, Yamaguchi M, Ishimura $\mathrm{M}$, Nishimura A et al. (1996). Toxicity and $\mathrm{LD}_{50}$ levels of the red tide dinoflagellate Heterocapsa circularisquama on juvenile pearl oysters. Aquaculture 144: 149-154.

Nielsen MV. (1993). Toxic effect of the marine dinoflagellate Gymnodinium galatheanum on juvenile cod Gadus morhua. Mar Ecol Prog Ser 95: 273-277.

Ohman MD, Hirche HJ. (2001). Density-dependent mortality in an oceanic copepod population. Nature 412: 638-641.

Place AR, Bowers HA, Bachvaroff TR, Adolf JE, Deeds JR, Sheng J. (2012). Karlodinium veneficum-The little dinoflagellate with a big bite. Harmful Algae 14: 179-195.

Place AR, Saito KA, Deeds JR, Robledo JAF, Vasta GR. (2008). A decade of research on Pfiesteria spp. and their toxins: Unresolved questions and an alternative hypothesis. In: Botana LM (ed.) In. Seafood and Freshwater toxins. CRC Press: New York, pp 717-751.

Poulsen LK, Moldrup M, Berge T, Hansen PJ. (2011). Feeding on copepod fecal pellets: a new trophic role of dinoflagellates as detritivores. Mar Ecol Prog Ser 441: 65-77.

Sheng J, Malkiel E, Katz J, Adolf JE, Place AR. (2009). A dinoflagellate exploits toxins to immobilize prey prior to ingestion. Proc Natl Acad Sci USA 107: 2082-2087.

Schnepf E, Drebes G. (1986). Chemotaxis and appetence of Paulsenella sp. (Dinophyta) an ectoparasite of the marine diatom Streptotheca thamesis Shrubsole. Planta 167: 337-343.

Shumway SE, Burkholder JM, Springer J. (2006). Effects of the estuarine dinoflagellate Pfiesteria shumwayae (Dinophyceae) on survival and grazing activity of several shellfish species. Harmful Algae 5: 442-458.

Skovgaard A. (1998). Role of chloroplast retention in a marine dinoflagellate. Aquat Microb Ecol 15: 293-301.

Spero HJ. (1985). Chemosensory capabilities in the phagotrophic dinoflagellate Gymnodinium fungiforme J Phycol 21: 181-184.

Stoecker DK, Johnson MD, deVargas C, Not F. (2009). Acquired phototrophy in aquatic protists. Aquat Microb Ecol 57: 279-310.

Strickler JR, Bal AK. (1973). Setae of the first antennae of the copepod Cyclops scutifer (Sars): their structure and importance. Proc Natl Acad Sci USA 70: 2656-2659.

Tang YZ, Gobler CJ. (2009). Cochlodinium polykrikoides blooms and clonal isolates from the northwest Atlantic coast cause rapid mortality in larvae of multiple bivalve species. Mar Biol 156: 2601-2611. 
Van Wagoner RM, Deeds JR, Tatters AO, Place AR, Tomas CR, Wright JLC. (2010). Structure and relative potency of several karlotoxins from Karlodinium veneficum. J Nat Prod 73: 1360-1365.

Vaqué D, Felipe J, Sala MM, Calbet A, Estrada M, Alcaraz M. (2006). Effects of the toxic dinoflagellate Karlodinium sp. (cultured at different N/P rations) on micro and mesozoo-plankton. Sci Mar 70: 59-65.
Vogelbein WK, Lovko VJ, Shields JD, Reece KS, Mason PL, Haas LW et al. (2002). Pfiesteria shumwayae kills fish by micropredation not exotoxin secretion. Nature 418: 967-970.

Waggett RJ, Tester PA, Place AR. (2008). Anti-grazing properties of the toxic dinoflagellate Karlodinium veneficum during predator-prey interactions with the copepod Acartia tonsa. Mar Ecol Prog Ser 366: 31-42.

Supplementary Information accompanies the paper on The ISME Journal website (http://www.nature.com/ismej) 